\section{ENGAGING WITH THE BENEFICIARIES \\ IN REFORMING HEALTH CARE. A CASE \\ STUDY OF PATIENT INVOLVEMENT \\ IN THE REFORM OF PSYCHIATRIC CARE \\ IN THE CZECH REPUBLIC}

\section{Karolína DOBIÁŠOVÁ \\ Miriam KOTRUSOVÁ \\ Magdalena WOLFOVÁ}

\author{
Karolína DOBIÁŠOVÁ \\ Associate Professor, Institute of Sociological Studies, \\ Faculty of Social Sciences, \\ Charles University, Prague, Czech Republic \\ Tel.: 0042-0731-147.170 \\ E-mail: karolina.dobiasova@fsv.cuni.cz

\section{Miriam KOTRUSOVÁ} \\ Associate Professor, Institute of Sociological Studies, \\ Faculty of Social Sciences, \\ Charles University, Prague, Czech Republic \\ E-mail: miriam.kotrusova@seznam.cz
}

\section{Magdalena WOLFOVÁ}

Researcher, Institute of Sociological Studies,

Faculty of Social Sciences,

Charles University, Prague, Czech Republic

E-mail: magdalena.wolfova@gmail.com

\footnotetext{
* The article was supported by the Czech Science Foundation under the project 'Civic Commitment and Health Care' No. [17-01116S].
}

\begin{abstract}
The involvement of patients and their families in healthcare policymaking has been a general trend in recent years. This tendency can be observed also in the process of the current reform of psychiatric care in the Czech Republic, which should gradually shift the focus of psychiatric care from large facilities to community care. Organizations representing patients and their families are among the key stakeholders in this reform. The present study analyses semi-structured in-depth interviews and documents with the objective to map and evaluate the process of patient involvement in the reform from its launch to its implementation in 2012-2019.

The study identifies the major barriers to patient involvement - on the part of the patients and their organizations, professionals (healthcare professionals, care providers, administration, policymakers), as well as the whole society. It becomes clear that the reform encourages patient involvement, with a palpable shift from consultation to involvement. Still, there are many obstacles to patient involvement in the Czech Republic: the mental state, social and economic situation of the patients, paternalism on the part of care providers, tokenism or stigmatization of mentally ill people.
\end{abstract}

Keywords: mental healthcare policy, patient's involvement, patients and caregivers organizations, psychiatric care reform. 


\section{Introduction}

Mental disorders have been major causes of sickness and disability all over the world. One in four people worldwide experience mental or neurological disorder at some point in their life; in the European region, mental disorders are responsible for $30-40 \%$ of chronic sick leave, costing some $4 \%$ of GDP (OECD, 2018). In addition, the unpredictable developments associated with the COVID-19 pandemic, the subsequent lockdown and the economic impact increase the risk of mental health issues (Moreno et al., 2020). In the context of mental health policies, the World Health Organisation (WHO) stresses the role of patient empowerment, consisting in the strengthening of their rights, encouraging their autonomy, finding opportunities for their participation in decision-making processes and sharing responsibility for their own mental health (WHO, 2015).

Since the 1990s, new tendencies have gained ground in psychiatric care to replace institutional care with community care (Muijen and McCulloch, 2019; Semrau et al., 2011). In many EU countries, a certain part of psychiatric care has been moved from inpatient facilities to community-based mental health services, which offer people with mental disorders professional assistance in their natural social environment, relying on their functional networks (Keet et al., 2019). The speed and extent of such changes varies considerably across the EU (Knapp et al., 2007). In most countries institutional care still prevails over community care (Semrau et al., 2011; Dlouhý, 2014; Krupchanka and Winkler, 2016), most conspicuously in the Central and Eastern European (CEE) region (Peč, 2019; Hudson and Dragomirecká, 2019; Scheffler, Shumway and Chereches, 2020). Reforms of psychiatric care in CEE countries are hindered by several major constraints, including the persistent stigmatization and discrimination of people with mental disorders; relatively high cost of community care in countries with limited healthcare resources; and the lack of experts at all levels, from psychiatrists to social workers (Skuse, 2018). The EU has allocated financial resources within its structural funds for its member and candidate states to carry out reforms of mental health care. These resources are currently used, e.g., in the Czech Republic (CR), Poland and Turkey (Muijen and McCulloch, 2019).

In the EU, there is a strong policy commitment that patients and their families should partake in the mental healthcare policy. It is argued that patient involvement also improves the quality of care and leads to effectiveness of services (Colombo et al., 2012; Jørgensen and Rendtorff, 2018). Within the decision-making processes in psychiatric care, the accent has gradually shifted from the providers to the recipients, with patient involvement taking various forms at various levels (Hickey and Kipping, 1998; Tait and Lester, 2005; Tambuyzer, Pieters and Van Audenhove, 2014). While western EU countries show high levels of patient involvement in psychiatric care, CEE countries, lacking a tradition in this process, have only just started to allow patients some level of power (WHO, 2008; Krupchanka and Winkler, 2016).

The aim of the present article is to review the progress of the mental health reform in the Czech Republic in terms of patient involvement as well as identify the greatest 
barriers of patient involvement in the reform. First, we briefly describe the Czech mental health care system and its reform. After outlining the theoretical and methodological approach used in our study, the research results on patient involvement in the mental health care reform in the Czech Republic are presented and discussed.

\section{Overview of mental health care system in the Czech Republic}

Mental health care in the Czech Republic (CR from here on) is financed via the health insurance system, taxes, and regional budgets (Dlouhý, 2014). Like in other CEE countries, national expenses on mental healthcare are below EU-15 average (Krupchanka and Winkler, 2016), while more than half of public mental health expenditures are allocated to inpatient care (Broulikova, Dlouhy and Winkler, 2020).

The CR has a long tradition of large psychiatric hospitals; the average number of beds in one psychiatric hospital was 492 in 2014, which is way above the EU-15 average of 185 beds per facility (Höschl, Winkler and Peč, 2012). In addition, Czech psychiatric hospitals have been criticised for their substandard conditions and low quality of care for long-term patients (Kalisova et al., 2018). Community services focusing on mental health are not fully developed (Tušková, Dobiášová and Duškov, 2020).

The process of patient involvement has gained strength in the $\mathrm{CR}$ in recent years, not only in mental health care, but also across the whole Czech healthcare system. Self-help groups for patients and their families, as well as patient advocacy groups have gained increasing influence in the process of mental health policymaking (Honová, Numerato and Kondrátová, 2019).

\subsection{Reform of psychiatric care in the Czech Republic}

A new chapter of mental health care development in the CR opened in 2013 with the announcement of the Strategy for the Reform of Psychiatric Care (SRPC), designed to fulfil the commitments ensuing from international strategic and human-rights documents (Ministry of Health, 2013). In accordance with the WHO recommendations, the Strategy proposes a new structure of the mental healthcare system with an emphasis on community care and the involvement of communities, families and recipients of the care in the planning and development of mental health policies (WHO, 2011); the costs of the reform are largely covered from EU Structural and Investment Funds (ESIF) (Duškov, 2019).

The basic aim of the reform is to improve the quality of life of people with mental disorders (Ministry of Health, 2013). The psychiatric reform expects the new system of mental health care to stand on four pillars (see Figure 1). The principal systemic change consists in a new element which is to be incorporated in the current system - the Centres for Mental Health (CMH). CMHs are expected to provide community care by multi-disciplinary teams and coordinate the provided care with other healthcare facilities and social services in the region (Ministry of Health, 2013; Dobiášová et 
al., 2016). The core of the reform focuses on creating a network of CMHs and lowering the number of beds in large mental hospitals (Prototopová, 2018).

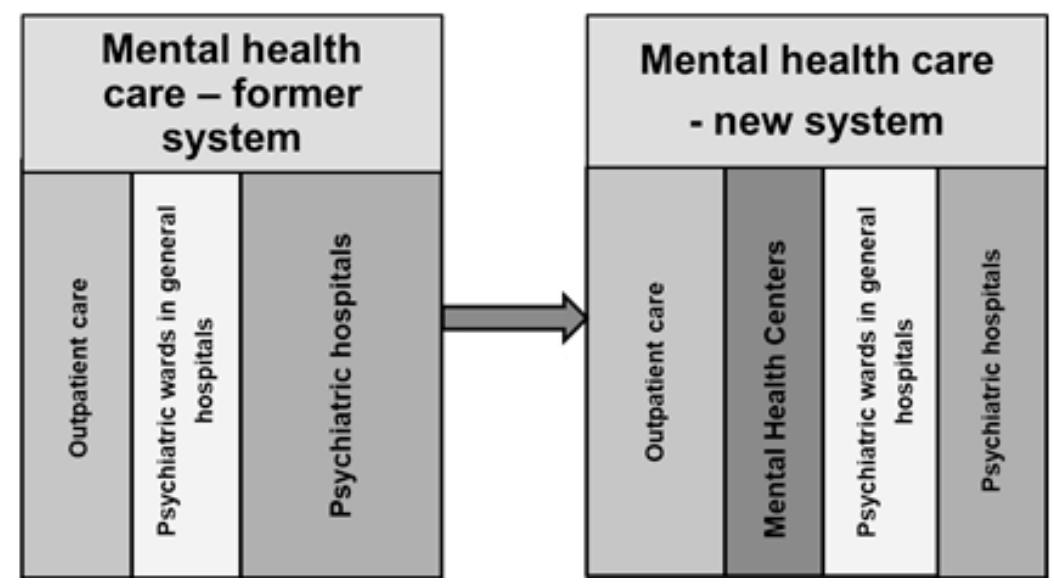

Figure 1: Institutional Changes within the Reform of Psychiatric Care

Source: Authors, based on the Ministry of Health (2013)

\section{Theoretical perspective:}

\section{patient involvement in the health care and its constraints}

Higher patient involvement in healthcare is one of key trends in the reforms of healthcare systems in western economies (Church, Saunders and Wanke, 2002; Wait and Nolte, 2006; Tritter, 2009; Mockford et al., 2012; Carman et al., 2013). When referring to the focus on the role of patients in healthcare, the authors use various terms interchangeably, such as patient empowerment, patient involvement, public and patient involvement, patient activation, patient engagement, patient enablement, patient participation (Boudioni, McLaren and Lister, 2017; Castro et al., 2016, McAllister, 2015; Carman et. al., 2013; Triterr, 2009). The present article uses the term 'patient involvement' although the authors are fully aware that it should also include the involvement of the patient's caregivers and on the general level also the public (Dent and Pahor, 2015). Our article shall adopt the definition of patient involvement coined by Robinson et al. (2008) 'as the deliberate activation of patients in their own care or the development of health care'.

Patient involvement is driven by clear evidence that patients and citizens can considerably influence healthcare policies at all stages, from the design to the provision of the care (Ocloo and Matthews, 2016). The pressure to allow patients a stronger say is often associated with the neoliberal attitudes towards public administration, emphasizing the focus of public services on the client-citizen's satisfaction. At the same time, it was presumed that a higher level of patients' autonomy and involvement could encourage competition and efficiency, eventually lowering healthcare expens- 
es (Dent and Pahor, 2015). The efforts to increase the involvement of patients were also driven by dissatisfaction with the paternalistic approach in healthcare which reduced patients to passive recipients of care, incapable of any autonomous control (Clark, Glasby and Lester, 2003; Dent and Pahor, 2015).

Dent and Pahor (2015) proposed a comparative patient involvement framework, describing three ideal types of patient involvement: choice, voice and co-production. The choice type understands patients as consumers; the voice stresses their active participation in decision-making processes; and co-production concentrates on individual or collective engagement of patients (and caregivers) in the delivery of healthcare services in collaboration with health professionals. Carman et al. (2013) devised a multidimensional framework for the continuum of patient involvement in healthcare, combining three levels of healthcare organization and three levels of patient involvement. Carman et al. (2013) see a causal relationship between the level of involvement and the information flow between patients and care providers, the patients' opportunity to influence the provided care, and the way patients or patient organizations participate in decision-making processes. Similarly, Tambuyzer, Pieters and Van Audenhove (2014) relate patient involvement to their power, defined by the extent and quality of their access to information. The lower degree of Carman's continuum, so-called 'consultation', means that patients are involved, but with limited power and/or authority in the process. At the higher degree of the continuum, the 'involvement', patients share authority and responsibility with health professionals and act as partners in defining and designing the agenda. The highest degree of the continuum is 'partnership and shared leadership', in which the care reflects not only the medical point of view, but also the general experience and the patient's stance; decisions about care are made jointly with respect to all relevant information which is universally shared (Carman et. al., 2013).

From the point of view of the healthcare system, Carman et al. (2013) divide care provision to the lowest level of individual and direct care, the middle level of institutional structure and management, and the highest level of policymaking. At the lowest level, patient involvement consist in the consideration of the patient's values, experience and prospects in prevention, diagnosis and therapy, including the coordination of activities related to the patient's health and selection of health care providers. At the middle institutional level, patients' values, experience and prospects are considered in healthcare facilities (such as hospitals or outpatient offices); patients act as a partner of the healthcare institutions in the process of care planning, provision and evaluation. At the top level, patients and their families are engaged in the design, implementation and evaluation of national and local healthcare policies. Carman et al. (2013) and Tambuyzer, Pieters with Van Audenhove (2014) point out that patients can either act for themselves or be represented by organizations at the middle and upper levels of healthcare systems. Tambuyzer, Pieters and Van Audenhove (2014) divide the organization structure of patient involvement into the micro level (individual health care plan, selection of provider and therapy), mezzo level (representation 
of patients by associations, membership in advisory bodies of healthcare providers), and macro level (patient involvement in policymaking).

Patient involvement itself, as Carman et al. (2013) suggest, is affected by three factors: 1 - the patient's personality, motivation, willingness and ability to participate at different levels of organization, their opinions and beliefs, health literacy, or state of health, with some patients dealing with other issues, such as low income or cognitive problems; 2 - healthcare providers and their attitudes towards patient involvement; and 3 - the society and its social standards, political atmosphere, legislation and public policy. Policymakers can support patients by shaping formal and informal conditions for their involvement, such as public discussions or hearings, or their participation in legislative processes. Patient involvement can be greatly encouraged by a suitable legislative framework (Carman et. al., 2013). Hickey and Kipping (1998, p. 86) also specify certain constraints on the continual process of patient involvement: 'user issues, organizational culture, professional culture and wider society'.

\section{Methodology}

The study is based on a qualitative research, combining an analysis of public policy documents and the output from 15 semi-structured in-depth interviews with representatives of different groups of stakeholders in the reform of psychiatric care.

The 15 interviews were conducted both with members of the so-called elite, and with non-elite actors who play a crucial role in the policymaking process (Fischer, Miller and Sydney, 2007). The four elite stakeholders represented the key institutions participating in the management of the mental health care reform (a top manager at the Ministry of Health $(\mathrm{MoH})$ of the $\mathrm{CR}$, a member of the Executive Board for the Reform of Psychiatric Care, a member of the Advisory Board for the Reform of Psychiatric Care, a member of the Czech MoH's Patients' Council responsible for mental health). The other 10 informants represented the organizations of psychiatric patients (8 informants) and organizations of families of people living with mental disorders ( 2 informants). The main selection criteria were their formal involvement and active participation in designing and implementing the reform at various levels. One informant represented the National Institute of Mental Health (NIMH), mainly responsible for implementation of projects on patient involvement and their evaluation within the psychiatric care reform.

The interviews took place between February 2018 and December 2018, with the length ranging from 50 minutes to 2 hours; data collection continued until the point of data saturation was reached. All interviews were recorded verbatim and thematic analysis was used to facilitate the identification of individual topics across the opinions expressed by individual informants. The transcribed interviews were analyzed using NVivo11.

The empirical evidence based on in-depth interviews was enriched by desk research of relevant documents such as scientific articles, strategic documents, laws 
Table 1: Sample of informants

\begin{tabular}{ll}
\hline \multicolumn{1}{c}{ Informant } & \multicolumn{1}{c}{ Institution } \\
\hline Informant 1 & Ministry of Health of the Czech Republic \\
Informant 2 & Executive Board for the Reform of Psychiatric Care \\
\hline Informant 3 & Advisory Board for the Reform of Psychiatric Care \\
Informant 4 & National Institute of Mental Health \\
\hline Informant 5 & Patients' Council within the Ministry of Health \\
Informant 6 & Patient organization A \\
Informant 7 & Patient organization B \\
Informant 8 & Patient organization C \\
Informant 9 & Patient organization D \\
Informant 10 & Patient organization E \\
Informant 11 & Patient organization F \\
Informant 12 & Patient organization G \\
\hline Informant 13 & Patient organization H \\
\hline Informant 14 & Organization representing families of people with mental disorders A \\
\hline Informant 15 & Organization representing families of people with mental disorders B \\
\hline
\end{tabular}

Source: Authors

and bills, decrees, implementation guides, information materials of various patient organizations, websites of key stakeholders, internal document of public authorities and patient organizations.

\section{Research results}

The following part of the article presents the main results of the data analysis. At the beginning we describe the development of the psychiatric reform in time, with the main emphasis placed on patient involvement in different phases of policy formulation and policy implementation. Then we identify the main constraints on patient involvement in psychiatric care reform.

\subsection{Development of patient involvement in the reform of psychiatric care}

The current Strategy for the Reform of Psychiatric Care (SRPC) was designed in collaboration with most stakeholders: the Ministry of Health $(\mathrm{MoH})$, the Ministry of Labour and Social Affairs, health insurers, professional associations, representatives of healthcare facilities and regions, and representatives of patients and their families (Ministry of Health, 2013). The main milestones in the process of formulation and implementation of the psychiatric care reform in terms of patient involvement in 2012-2019 are summarized in Table 2. 
Table 2: Patient involvement milestones in the implementation of the Reform of Psychiatric Care

\begin{tabular}{|c|c|c|}
\hline Year & Reform of Psychiatric Care & Patient Involvement \\
\hline 2012 & $\begin{array}{l}\text { Design of the Strategy for the Reform } \\
\text { of Psychiatric Care (SRPC) }\end{array}$ & $\begin{array}{l}\text { Founding of the Platform for the Transformation } \\
\text { of the Mental Health Care System (Platform) } \\
\text { Clients participate in SRPC design }\end{array}$ \\
\hline 2013 & SRPC publication & \\
\hline 2014 & $\begin{array}{l}\text { Setup of SRPC implementation workgroups } \\
\text { Deceleration of SRPC implementation }\end{array}$ & \\
\hline 2015 & $\begin{array}{l}\text { SRPC implementation workgroups continue } \\
\text { SRPC implementation stops }\end{array}$ & $\begin{array}{l}\text { Patients appointed to workgroups after complaints } \\
\text { Complaints from the Platform - open letters to } \\
\text { PM and MoH about the progress of the reform }\end{array}$ \\
\hline 2016 & SRPC implementation stagnant & $\begin{array}{l}\text { Unsuccessful talks between patient represen- } \\
\text { tatives and } \mathrm{MoH} \text { about the future of the reform } \\
\text { implementation }\end{array}$ \\
\hline 2017 & $\begin{array}{l}\text { Appointment of the Advisory Board } \\
\text { and Executive Board, development } \\
\text { and launch of implementation projects }\end{array}$ & $\begin{array}{l}\text { Representatives of patients and families } \\
\text { in the Advisory Board }\end{array}$ \\
\hline 2018 & Execution of implementation projects & $\begin{array}{l}\text { Upon complaints from patient organizations, a } \\
\text { patient representative appointed to the Executive } \\
\text { Board }\end{array}$ \\
\hline 2019 & $\begin{array}{l}\text { Execution of implementation projects } \\
\text { Appointment of the Government Council } \\
\text { for Mental Health }\end{array}$ & $\begin{array}{l}\text { Upon complaints from patient organizations, two } \\
\text { seats on the Executive Board reserved for patient } \\
\text { representatives } \\
\text { Representatives of patients and caregivers have } \\
\text { permanent seats in the Mental Health Council }\end{array}$ \\
\hline
\end{tabular}

Source: Authors

From the very beginning, patients' organizations were considered one of the crucial stakeholders. The Platform for the Transformation of the Mental Health Care System (Platform) was established in 2012, associating providers of community services for mentally ill people, organizations of patients and their families. The goal of the Platform has been to advocate the transformation and deinstitutionalization of mental health care in the Czech Republic. An important driver of the SRPC was the Platform's pressure on transformation of the whole system, considered the only satisfactory solution to the unacceptable state of mental health care (Ministry of Health, 2013; Hollý, 2014).

The reform implementation workgroups were set up in 2014, covering the various areas of mental health care (Ministry of Health, 2013). When the workgroups first met in 2014, representatives of patients criticized the fact that, contrary to the original promises, no representatives of patients were invited to take part in the workgroups (Open letter of the Platform, 2014). The involvement of patients in the SRPC implementation workgroups occurred later, in 2015 as a result of pressure from patients' organizations (Kolumbus, 2015; Jaroš, 2016). But even then, the way in which patients were engaged in the workgroups was criticized both by those responsible for 
the implementation of the reform and by the patients themselves: 'The workgroups were chaotic, no real management, no clear objective. Then they opened it to clients who went there with no clear idea what it is supposed to be for, and neither did the rest of them know what it was for' (I2).

The implementation of the reform of psychiatric care was delayed after the Minister of Health was replaced and the reform lost political backing, nearly stopping in 2015 (Duškov, 2019; Gabriel, 2016). That was when the Platform intervened again; its members sent an open letter to the Prime Minister and the Minister of Health, articulating their concerns about the progress of the reform.

In 2015-2016, representatives of the Platform met with representatives of the $\mathrm{MoH}$ to discuss the future of the reform, but the implementation of the reform stagnated (Kolumbus, 2015). In 2017, the implementation of individual reform projects funded by ESIF began. The MoH set up a dedicated team of experts who should carry out the reform full-time. The Advisory Board was appointed to guarantee the reform implementation (ČPS, 2017). One chair on the board was reserved for a representative of patients and one for a representative of caregivers. The Executive Board for the Reform of Psychiatric Care was established as the key body of the reform, appointed to 'manage and coordinate all activities within the reform' (ČPS, 2017). In addition to representatives of the key ministries, health insurance funds, administrators of the implementation projects, members of the Psychiatric Society, representatives of regions and the NIMH, the Executive Board also reserved a seat for a representative of the patients. This seat was offered about six months after the Executive Board was set up, in response to repeated complaints from patients: 'So, I went to knock on the door again and again, and, in the end, they opened it and told me they would have me on the board. Meaning I would have a say' (I12).

Since 2017, several implementation projects have been running within the psychiatric care reform, focusing mainly on deinstitutionalization and support for new services (especially the CMHs) and destigmatisation (Protopopová, 2018).

Within the implementation projects, working positions of regional projects coordinators were installed. Most of the coordinators were recruited from among the patients. The role of the coordinators was to communicate with and connect the key stakeholders at the regional level with the aim of creating a regional services network: 'The regional coordinator invites all people who take part in the reform, including patients. They all should meet to discuss the relevant questions relating to the implementation of the reform. They should communicate with the region, so that the regional authorities can reflect their remarks in their healthcare policies. The group should include two representatives of patients who can pursue their interests and protect their rights within the group' (I4).

With respect to the coordinator position, though, some informants (I4, I8) expressed concerns about the sustainability of this form of patient involvement in policymaking after the ESIF funding expires. 
One of the crucial parts of the Destigmatization project managed by the NIMH focused on efficient support for patients and their families (Protopopová, 2018). A workgroup consisting of representatives of patients and experts was set up in late 2018 to determine and analyze the patients' needs and to provide this information to higher levels of the reform management. The workgroup also disseminated news about the reform among patients.

A patient education programme was launched in 2019 aimed to increase the patients' awareness and competence, especially in relation to the reform of psychiatric care, the empowerment of people with mental illness and human rights of mentally disabled people. The education programme should produce 'ambassadors', i.e., people who have experienced mental disorder and who would be willing and able to speak about their experience in public to help destigmatise people with mental disorders: 'They should be able to modify their story to the specific audience, whether they go to visit a secondary school or a mental hospital' (I4).

The involvement of patients in the psychiatric care reform took place especially at the macro level of mental health care policy. In terms of the patient involvement framework presented by Carman et al. (2013) and Tambuyzer, Pieters and Van Audenhove (2014), it is important to note that the reform generated systemic changes also at the meso level of mental health care. The multidisciplinary teams set up at the $\mathrm{CMH}$ must include peer consultants, i.e., people who have personal experience with a mental disorder which they use in their support of other patients (Ministry of Health, 2016).

The policy of mental health was given a substantial impulse with the appointment of the Government Council for Mental Health (MH Council) in 2019. The MH Council is supposed to guarantee the continuity of the reform steps to make the reform less vulnerable to changes of priorities caused by the four-year election cycle (Scheffler, Dimick and Duškov, 2020). The MH Council is a permanent body of the Czech Government and it should continue to coordinate the policies of mental health. A substantial shift in the attitude to patient involvement is evidenced by the fact that the permanent members of the $\mathrm{MH}$ Council include representatives of patients and caregivers (Ministry of Health, 2020).

Informants (I1, I4, I2, I7, I5, I9, I12 and I15) agreed about the positive effect on patient involvement created by various parallel processes of patient involvement institutionalization at the level of the Czech healthcare system. The MoH has recently focused on encouraging the patients' voice in health policymaking. In 2017, the Department of Patient Rights Support was set up as a permanent part of the organizational structure of the $\mathrm{MoH}$ and the Minister of Health appointed the Patients' Council as a permanent advisory body to represent patients' voice at the $\mathrm{MoH}$ (Ministry of Health, 2017). The Patients' Council consists of patient organizations representatives. The statutes of the Council define its responsibility as assessing proposals and documents of legislative and non-legislative nature, issuing statements and providing consultations (Dobiášová, Kotherová, Numerato, 2021). 


\subsection{Identified constraints on patient involvement in the reform}

We identified specific constraints to patient involvement, which could be divided into four categories: 1 . on the part of patients and their families, 2. on the part of patients' organizations, 3. on the part of the mental health care professionals and psychiatric care reform managers, and 4 . on the part of the whole society.

\subsubsection{Constraints on the part of patients and their families}

These are mostly associated with the personality, background and socio-economic status of the patients and their families. Informants (I10, I11, I13 and I14) from among patients generally agreed that it was difficult to defend their lay opinions in front of a body of professionals: '... the Executive Board, there are mainly people from mental hospitals, there are representatives of health insurers - they are all professionals. And the person with real personal experience is a minority of one, against some twenty professionals. And that person is to defend patients' interests in the group. That is pretty tough' (I12).

Other reported constraints related to the character of the illness, which can, at times, prevent patients from participating: '... this particular disorder is specific, it affects thinking, cognition, self-confidence (...) it hampers all the qualities you need to pursue your interests actively' (I6)

Informants repeatedly suggested that there should be at least two representatives of patients, who could replace each other or support each other in the talks with professionals: 'So, I think one person is not enough. There needs to be a team of people with certain motivation and hope ...to be able to step in' (I12).

The socio-economic situation is another considerable issue as patient representatives often participate in the implementation process of the psychiatric care reform as volunteers. All informants identified the lack of money and overwork as the major obstacle to patient involvement in the reform implementation process: 'To tell the truth, I do not have the time to do it. For not a single penny' (I7).

Some informants (I4, I8) believed that the patients who take part in the implementation process are mostly active people treated in outpatient facilities and inpatients are excluded. 'From my point of view, patients in mental hospitals know very little about the reform' (I8)

\subsubsection{Constraints on the part of patient organizations}

The biggest problem of patient organizations, mentioned by all informants, is the lack of people who would be willing to participate. As indicated by the interviewers, the patient movement seems to be unable to reach a common stance due to certain petty enmities between individual organizations, regarding mainly the distribution of power and funding. Patient organizations are not recognized in the Czech legislation which drives most of them to work as NGOs (Tušková, Dobiášová and Duškov, 2020) and depend on volunteer work or funding from various ad hoc projects. Conflicts between organizations are also fueled by the fact that some representatives of 
patients' organizations have jobs within the reform implementation process, while others participate in unpaid positions. Informants believed that consequently, the leading positions within the reform implementation processes can be taken by people who follow their own interests with little will to collaborate with other patients: 'Everybody secretly thinks they could make more money if they could secure a better position within the implementation of the reform' (I8). This aspect could threaten the credibility of the reform and reduce the clients' motivation to participate. Some of the disunity within the patient movement can be attributed to different expectations associated with the reform. Informants often mentioned divergent opinions of organizations representing patients and those representing their families (I2, I4, I6, I7, I12, I14). While patients advocate more autonomy for mentally ill people, their families seem to prefer services which facilitate their daily care: 'Patients generally do not want to be taken to hospitals, locked somewhere, they want to lead a normal life, while their parents call for respite services, day-care centers, even hospital care, they need to take a rest and know that their children are taken care of' (I2). Different organizations therefore advocate different routes of development for the reform, e.g., which segments of services should be more supported.

\subsubsection{Constraints on the part of mental health care professionals and psychiatric care reform managers}

The traditional medical paternalistic paradigm is still prevalent in mental health care in the Czech Republic (Kalisová et al., 2019). All informants agreed that the prevalent paternalistic attitude obstructs patient involvement at all levels of the psychiatric care reform and the mental health care system. Clients are often dismissed as not being equal partners: 'I believe the people still have those paternalistic patterns of thinking. They tell you: 'They (patients) don't know anything. We have been trained and educated to know what they need.' They say they should be the ones to decide because they bear the responsibility' (I3)

Informants pointed out that the reform aspires to strengthen the role of patients at the macro and meso levels, but there is no encouragement on the micro level: 'In reality, patients rarely get any information about the therapy' (I3)

Participation efforts are prone to tokenism (asking for patient involvement but not taking it seriously or enabling it to be effective), which reduces users to the role of 'mascots' who are only supposed to legitimize the process in which they are seemingly involved (Honová, Numerato and Kondrátová, 2019): 'Sometimes, I’m afraid, it is only about checking it off, to demonstrate that the representative (of patients) was there' (I12).

\subsubsection{Constraints on the part of the whole society}

The general attitude to mental disorders is the crucial factor defining the extent to which patients can participate in decision-making. Such attitudes are formed and influenced by the whole society. As indicated by the poll conducted by the Public 
Opinion Research Centre in 2019, the perception of mentally ill people among the Czech public remains negative. Some $60 \%$ of respondents admitted they 'wouldn't prefer mentally ill people as neighbors' (CVVM, 2019). Negative experience with general acceptance was reported by several informants: 'When you develop a mental disorder, others just label you a fool' (I14).

\section{Discussions}

The findings of this study reveal that the reform of psychiatric care in the Czech Republic has definitely managed to increase patient involvement at the national and regional levels of (macro) policymaking. Patient organizations became important stakeholders in the mental health care policy at the national level (the Ministry of Health) as well as at the level of regions where they participated in the implementation of reform. Measures designed to support patient involvement were also taken at the meso level, such as introducing peer consultants as compulsory positions within psychiatric care. In this case, the Czech Republic has followed the mental health care trends of Western countries. For example, mental health care services in the UK have seen increasing numbers of peer workers and even increasing numbers of user-led services (Brosnan, 2012; Rutter et al., 2004). Also, in Norway, users are involved in the management of community mental health hospitals (Rise, Solbjør and Steinsbekk, 2013).

Thanks to the reform, patient involvement at the macro and meso levels of the healthcare system shifted from the lowest degree defined by Carman et al. (2013) as 'consultation' to the higher degree of 'involvement'. Should the processes launched within the reform successfully continue, there is a good hope of reaching the degree of 'partnership'. So far, there have been no observable changes at the level of direct care. It can be presumed that the continuing reform process at the higher levels of health care system will in time affect the micro level, too, as Carman et al. (2013) and Tambuyzer, Pieters and Van Audenhove (2014) assumed. Similarly, mental health care reform measures in countries like Ireland, The Netherlands and Switzerland led to involvement of patients and caregivers in decision-making at all levels, from individual care choices to decisions about the development of local mental health care to participation in the making and implementation of national mental health policies (Brosnan, 2012; Placella, 2018).

The initial stages of the Czech psychiatric care reform were characterized by bottom-up involvement of patients' organizations that mobilized and exerted pressure on changes in the mental health care system. Similarly, changes of the mental health care system have been also primarily driven by bottom-up pressure from patients' organizations, both in a number of Western countries, for example Ireland (Brosnan, 2012) and in CEE countries like Serbia (Milicević Kalasić, Kalašić Vidović and Anđelković, 2020) or Romania (Sfetcu and Ungureanu, 2020). Later, during the Czech mental health care reform's implementation, top-down patient involvement took place as representatives of patients and caregivers became permanent members 
of government institutions responsible for the mental health care reform. The role of patients in the reform of psychiatric care has become strengthened by the parallel processes that seek to institutionalize public involvement at the level of the entire healthcare system too. Public involvement institutionalization has contributed to the establishment of an effective communication channel between patients and healthcare authorities. Patients' and caregivers' participation in government institutions may serve as an example of good practice for other CEE countries where patients' and caregivers' organizations have been pushing for mental health policy reforms but they have been faced with limited power in decision-making processes and their lack of representation at government level (Scheffler, Shumway and Chereches, 2020).

The study has also identified a number of constraints to patient involvement in mental health care corresponding to those mentioned by international studies (Hickey and Kipping, 1998; Carman et al., 2013; Ocloo and Matthews, 2016). Despite strong policy commitment to involve patients in the mental health care reform, the practice is hampered by constraints on the level of the patients themselves and their organizations, on the level of the mental health care professionals and psychiatric care reform managers and finally on the level of the whole society.

Our findings reveal that some psychiatric patients do not have the capacity or desire to be involved due to their low self-confidence and self-stigmatization (Tambuyzer, Pieters and Van Audenhove, 2011) and their lower socio-economic status. Another concern is the representativeness of patient involvement (Ocloo and Matthews, 2016). Although the reform includes activities designed to increase awareness among patients there are still people, who are unaware of the reform and the opportunities for involvement. The motivation of patients to take part in reform is influenced also by the diagnosis and disease severity (Jørgensen and Rendtorff, 2018). Our research confirms a fact that patients with serious mental health problems or hospitalized patients are less involved.

At patients' organizations level, there is a problem with lack of human and financial resources resulting in rivalry between those organizations. Another problem is represented by some individuals working at key positions of reform implementations who prefer their own interests at the expense of the patients' interests. Ocloo and Matthews (2016) call such individuals who block patient involvement for personal reasons 'gatekeepers'. Another barrier of patient involvement identified is disunity of patient community in terms of targets of Czech mental health reform. The greatest conflicts arise between the patients and their caregivers.

On healthcare professionals' side there is a problem of persistent paternalistic attitude inherited from the communist period before 1989 and this attitude prevents the patients to be considered as equal partners. Just formal engagement of patients (tokenism) in reform is another risk which is confirmed by a number of studies (Rise, Solbjør and Steinsbekk, 2013).

Some of these constraints were taken into consideration in the reform, but some will need to be addressed at the level of the whole healthcare system (e.g., legisla- 
tive recognition and public funding of patient organizations, specific education for healthcare specialists in order to respect and pay attention to differences among people with mental health problems). Some issues (e.g., stigmatization of mentally ill people) will need to be tackled at the level of whole Czech society.

\section{Conclusions}

In many countries, including the Czech Republic, patients and their caregivers are an integral part of psychiatric care reforms. Psychiatric reform development in the Czech Republic brings hope that this trend will be maintained or even strengthened. Sustainability of patient involvement in mental healthcare could provide representation of patients in institutions as the Government Council for Mental Health and the Patients' Council of the Ministry of Health. Nevertheless, as the current mental health reform is largely funded from ESIF, there is a risk the patient involvement process could be disrupted after termination of funding from ESIF. New sources of funding will need to be secured from national sources. Although mental health care has been reformed in many countries, there is a lack of research evaluating patient involvement in the reform processes.

\section{References:}

1. Boudioni, M., McLaren, S. and Lister, G., 'A Critical Analysis of National Policies, Systems, and Structures of Patient Empowerment in England and Greece', 2017, Patient Preference and Adherence, vol. 27, no. 1, pp. 1657-1669.

2. Brosnan, L., 'Power and Participation: An Examination of the Dynamics of Mental Health Service-User Involvement in Ireland', 2012, Studies in Social fustice, vol. 6, no. 1, pp. 45-66.

3. Broulikova, H.M., Dlouhy, M. and Winkler, P., 'Expenditures on Mental Health Care in the Czech Republic in 2015', 2020, Psychiatric Quarterly, vol. 91, pp. 113-125.

4. Carman, K.L., Dardess, P., Maurer, M., Sofaer, S., Adams, K., Bechtel, C. and Sweeney, J., 'Patient and Family Engagement: A Framework for Understanding the Elements and Developing Interventions and Policies', 2013, Health Affairs, vol. 32, no. 2, pp. 223-231.

5. Castro, E., Van Regenmortel, T., Vanhaechtd, K., Sermeus, W. and Van Hecke, A., 'Patient Empowerment, Patient Participation and Patient-centeredness in Hospital Care: A Concept Analysis Based on a Literature Review', 2016, Patient Education and Counseling, vol. 99, no. 12, pp. 1923-1939.

6. Church, J., Saunders, D., Wanke, M., Pong, R., Spooner, C. and Dorgan, M., 'Citizen Participation in Health Decision-making: Past Experience and Future Prospects', 2002, Health Policy, vol. 23, no. 1, pp. 12-32.

7. Clark, M., Glasby, J. and Lester, H., 'Cases for Change: User Involvement in Mental Health Services and Research', 2003, [Online] available at https://pdfs.semanticscholar.org/5dc2/5 f57691f14fe94f510e63fd701b905dfa05a.pdf, accessed on December 2, 2019.

8. Colombo, C., Moja, L., Gonzalez-Lorenzo, M., Liberati, A. and Mosconi, P., 'Patient Empowerment as a Component of Health System Reforms: Rights, Benefits and Vested Interests', 2012, Internal and Emergency Medicine, vol. 7, no. 2, pp. 183-187. 
9. ČPS, 'Zpravodaj reformy péče o duševní zdraví (Mental Health Reform Rapporteur)', 2017, Česká psychiatrická společnost, [Online] available at http://www.reformapsychiatrie.cz/ wpcontent/uploads/2017/07/06_Zpravodaj_06_201706.pdf, accessed on November 5, 2019.

10. CVVM (Public Opinion Research Centre), 'Tolerance k vybraným skupinám obyvatel březen 2019. Tisková zpráva (Tolerance of Selected Population Groups - March 2019. Press Release)', 2019, Praha: Sociologický ústav [Online] available at https://cvvm.soc.cas.cz/ media/com_form2content/documents/c2/a4901/f9/ov190410.pdf, accessed on January 27, 2020.

11. Dent, M. and Pahor, M., 'Patient Involvement in Europe - A Comparative Framework', 2015, Journal of Health Organization and Management, vol. 29, no, 5, pp. 546-555.

12. Dlouhy, M., 'Mental Health Policy in Eastern Europe: A Comparative Analysis of Seven Mental Health Systems', 2014, BMC Health Services Research, vol. 14, no. 1, pp. 1-8.

13. Dobiášová, K., Kotherová, Z. and Numerato, D., 'Institutional Reforms to Strengthen Patient and Public Involvement in the Czech Republic since 2014', 2021, Health Policy, vol. 125, no. 5, pp. 582-586.

14. Dobiášová, K., Tuškova, E., Hanušová, P., Angelovská, O. and Ježkova, M., 'The Development of Mental Health Policies in the Czech Republic and Slovak Republic since 1989', 2016, Central European fournal of Public Policy, vol. 10, no. 1, pp. 35-46.

15. Duškov, I., 'Socioekonomický kontext duševních onemocnění a reforma psychiatrické péče v ČR jako veřejná strategie (The Socioeconomic Context of Mental Health and the Reform of Psychiatric Care in the Czech Republic as a Public Strategy)', 2019, Čes a slov Psychiat, vol. 115, no. 1, pp. 32-38.

16. Fischer, F., Miller, G.J. and Sydney, M.S., Handbook of Public Policy Analysis. Theory, Politics and Methods, CRC Press Taylor \& Francis Group, 2007.

17. Gabriel, J., Reforma psychiatrické péče (Psychiatric Care Reform), Praha: Dobré místo, 2016.

18. Hickey, G. and Kipping, C., 'Exploring the Concept of User Involvement in Mental Health through a Participation Continuum', 1998, Journal of Clinical Nursing, vol. 7, no. 1, pp. 83-88.

19. Hollý, M., 'Reform of the Psychiatric Care', 2014, Postgraduální Medicína, vol. 6.

20. Honová, P.A., Numerato, D. and Kondrátová, L., 'Zkušenost, expertiza a participace uživatelů: případ české reformy psychiatrické péče (Experience, Expertise and Users' Participation: The Case of the Czech Mental Health Care Reform)', 2019, Sociologický časopis/Czech Sociological Review, vol. 55, no. 5, pp. 615-640.

21. Höschl, C., Winkler, P. and Peč, O., 'The State of Psychiatry in the Czech Republic', 2012, International Review of Psychiatry, vol. 24, no. 4, pp. 278-285.

22. Hudson, C.G. and Dragomirecká, E., 'Decision Making in Psychiatric Reform: A Case Study of the Czech Experience', 2019, Central European fournal of Public Policy, vol. 13, no. 2, pp. 15-27.

23. Jaroš, J., 'Stav realizace Strategie reformy psychiatrické péče pohledem uživatelů psychiatrické péče (Status of Implementation of the Psychiatric Care Reform Strategy from the Perspective of Psychiatric Care Users)', 2016, Občanské sdružení Kolumbus, [Online] available at http://docplayer.cz/35619857-Stav-realizace-strategie-reformy-psychiatrickepecepohledem-uzivatelu-psychiatricke-pece-kveten-2016.html, accessed on October 12, 2019. 
24. Jørgensen, K. and Rendtorff, J.D., 'Patient Participation in Mental Health Care - Perspectives of Healthcare Professionals: An Integrative Review', 2018, Scandinavian fournal of Caring Sciences, vol. 32, no. 2, pp. 490-501.

25. Kalisova, L., Pav, M., Winkler, P., Michalec, J. and Killaspy, H., 'Quality of Care in Longterm Care Departments in Mental Health Facilities across the Czech Republic', 2018, The European fournal of Public Health, vol. 28, no. 5, pp. 885-890.

26. Keet, R., de Vetten-Mc Mahon, M., Shields-Zeeman, L., Ruud, T., van Weeghel, J., Bahler, M., and Nas, C., 'Recovery for All in the Community; Position Paper on Principles and Key Elements of Community-based Mental Health Care', 2019, BMC Psychiatry, vol. 19, no. 1, art. no. 174.

27. Knapp, M., McDaid, D., Thornicroft, G. and Mossialos, E., 'Mental Health Policy and Practice across Europe: An Overview', in Knapp, M., McDaid, D., Mossialos, E. and Thornicroft, G. (eds.), Mental Health Policy and Practice across Europe, Maidenhead: Open University Press, 2007, pp. 1-14.

28. Kolumbus, 'Výroční zpráva 2015 (Annual Report 2015)', 2015, Ústí nad Labem: Kolumbus, [Online] available at http://www.spolekkolumbus.cz/kolumbus/dokumenty-ke-stazeni/cat egory/2-vyrocni-zpravy?download=24:vyrocnizprava-2015, accessed on October 11, 2019.

29. Krupchanka, D. and Winkler, P., 'State of Mental Healthcare Systems in Eastern Europe: Do We Really Understand What Is Going On?’, 2016, BfPsych International, vol. 13, no. 4, pp. 96-99.

30. McAllister, M.P., 'Assessment of Patient Empowerment - A Systematic Review of Measures', 2015, PLoS One, vol. 10, no. 5.

31. Milicević Kalasić, A., Kalašić Vidović, O. and Anđelković, A., 'An Overview of Mental Health in Serbia', in Scheffler, R.M., Shumway, M. and Chereches, R.M. (eds.), Mental Health in Central and Eastern Europe: Improving Care and Reducing Stigma - Important Cases for Global Study, Singapore: World Scientific Publishing, 2020.

32. Ministerstvo zdravotnictví (Ministry of Health), 'Rada vlády pro duševní zdraví (Government Council for Mental Health)', [Online] available at https://www.mzcr.cz/ rada-vlady-pro-dusevni-zdravi/, accessed on November 24, 2020.

33. Ministerstvo zdravotnictví ČR (Ministry of Health), 'Příkaz ministra zdravotnictví k zř́izení Pacientské rady jako stálého poradního orgánu Ministra zdravotnictví ČR (Order of the Minister of Health to Establish the Patient Council as a Permanent Advisory Body to the Minister of Health of the Czech Republic)', 15/2017.

34. Ministerstvo zdravotnictví ČR (Ministry of Health), 'Psychiatric Care Reform Strategy', 2013.

35. Ministerstvo zdravotnictví ČR (Ministry of Health), 'Standard péče poskytované v centrech duševního zdraví(CDZ)(Standard of Care Provided in Mental Health Centers)' 2016, [Online] available at https://www.mzcr.cz/Legislativa/dokumenty/vestnik-c5/2016_11835_3442_11. htmlR, accessed on November 25, 2019.

36. Mockford, C., Staniszewska, S., Griffiths, F. and Herron-Marx, S., 'The Impact of Patient and Public Involvement on UK NHS Health Care: A Systematic Review', 2012, International fournal for Quality in Health Care, vol. 24, no. 1, pp. 28-38.

37. Moreno, C., Wykes, T., Galderisi, S., Nordentof, M., Crossley, N., Jones, N., et al., 'How Mental Health Care Should Change as a Consequence of the COVID-19 Pandemic', 2020, Lancet Psychiatry, vol. 7, no. 9, pp. 813-824. 
38. Muijen, M. and McCulloch, A., 'Reform of Mental Health Services in Eastern Europe and Former Soviet Republics: Progress and Challenges since 2005', 2019, BfPsych International, vol. 16, no. 1, pp. 6-9.

39. Ocloo, J. and Matthews, R., 'From Tokenism to Empowerment: Progressing Patient and Public Involvement in Healthcare Improvement', 2016, BM7 Quality and Safety, vol. 25, no. 8, pp. 626-632.

40. OECD/European Union, 'Health at a Glance: Europe 2018. State of Health in the EU Cycle', OECD Publishing, Paris/European Union, Brussels, 2018 [Online] available at https://doi. org/10.1787/health_glance_eur-2018-en, accessed on October 30, 2019.

41. Peč, O., 'Mental Health Reforms in the Czech Republic', 2019, BfPsych International, vol. 16, no. 1, pp. 4-6.

42. Placella, E., 'Supporting Community-based Care and Deinstitutionalization of Mental Health Services in Eastern Europe: Good Practices from Bosnia and Hercegovina', 2019, BfPsych International, vol. 16, no. 1, pp. 9-11.

43. Platforma pro transformaci, 'Stanovisko Platformy pro transformaci systému péče o lidi s duševním onemocněním v ČR k aktuálnímu stavu Reformy psychiatrické péče $\mathrm{v}$ ČR (Opinion of the Platform for the Transformation of the Care System for People with Mental Illness in the Czech Republic on the Current State of the Reform of Psychiatric Care in the Czech Republic)', 2015, [Online] available at http://www.pdz.cz/uploaded/ data/files/Dokumenty/Transformace/Stanovisko\%20Platformy\%20pro\%20transformaci\%20 syst\%C3\%A9mu\%20p\%C3\%A9\%C4\%8De\%20o\%20lidi\%20s.pdf, accessed on October 30, 2019.

44. Protopopová, D., 'Aktuální stav reformy psychiatrické péče (Current State of Psychiatric Care Reform)', 2018, [Online] available at https://pacientskeorganizace.mzcr.cz/res/file/ doc.-anders_reformace-psychiatricke-pece---or-11.3.-2020.pdf, accessed on October 30, 2019.

45. Rise, M.B., Solbjør, M. and Steinsbekk, A., 'Experiences from the Implementation of a Comprehensive Development Plan for User Involvement in a Mental Health Hospital: A Qualitative Case Study', 2013, International fournal of Social Psychiatry, vol. 60, no. 4, pp. 387-395.

46. Robinson, J.H., Callister, L.C., Berry, J.A. and Dearing, K.A., 'Patient-centered Care and Adherence: Definitions and Applications to Improve Outcomes', 2008, Journal of the American Academy of Nurse Practitioners, vol. 20, no. 12, pp. 600-607.

47. Rutter, D., Manley, C., Weaver, T., Crawford, M.J. and Fulop, N., 'Patients or Partners? Case Studies of User Involvement in the Planning and Delivery of Adult Mental Health Services in London', 2004, Social Science \& Medicine, vol. 58, no. 10, pp. 1973-1984.

48. Scheffler, R., Dimick, G. and Duškov, I., 'The Way Forward: Improving Mental Healthcare Systems in Central and Eastern Europe', in Scheffler, R.M., Shumway, M. and Chereches, R.M. (eds.), Mental Health in Central and Eastern Europe: Improving Care and Reducing Stigma - Important Cases for Global Study, Singapore: World Scientific Publishing, 2020.

49. Scheffler, R.M., Shumway, M. and Chereches, R.M. (eds.), Mental Health in Central and Eastern Europe: Improving Care and Reducing Stigma - Important Cases for Global Study, Singapore: World Scientific Publishing, 2020.

50. Semrau, M., Barley, E.A., Law, A. and Thornicroft, G., 'Lessons Learned in Developing Community Mental Health Care in Europe', 2011, World Psychiatry, vol. 10, no. 3, pp. 217-225. 
51. Sfetcu, R. and Ungureanu, M., 'An Overview of Mental Health in Romania', in Scheffler, R.M., Shumway, M. and Chereches, R.M. (eds.), Mental Health in Central and Eastern Europe: Improving Care and Reducing Stigma - Important Cases for Global Study, Singapore: World Scientific Publishing, 2020.

52. Skuse, D., 'Mental Health Services in Eastern Europe: Past, Present and Future. Editorial', 2019, BfPsych International, vol. 16, no. 1, p. 3.

53. Tait, L. and Lester, H., 'Encouraging User Involvement in Mental Health Services', 2005, Advances in Psychiatric Treatment, vol. 11, no. 3, pp. 168-175.

54. Tambuyzer, E., Pieters, G. and Van Audenhove, C., 'Patient Involvement in Mental Health Care: One Size Does Not Fit All', 2014, Health Expectations, vol. 17, no. 1, pp. 138-150.

55. Tritter, J.Q., 'Revolution or Evolution: The Challenges of Conceptualizing Patient and Public Involvement in a Consumerist World', 2009, Health Expectations, vol. 12, no. 3, pp. 275-287.

56. Tušková, E., Dobiášová, K. and Duškov, I., 'Czech Republic', in Scheffler, R.M., Shumway, M. and Chereches, R.M. (eds.), Mental Health in Central and Eastern Europe: Improving Care and Reducing Stigma - Important Cases for Global Study, Singapore: World Scientific Publishing, 2020.

57. Wait, S. and Nolte, E., 'Public Involvement Policies in Health: Exploring their Conceptual Basis', 2006, Health Economics, Policy and Law, vol. 1, no. 2, pp. 149-162.

58. World Health Organization, 'Mental Health Atlas 2011', [Online] available at https://www. who.int/mental_health/publications/mental_health_atlas_2011/en/, accessed on January $15,2020$.

59. World Health Organization, 'Policies and Practices for Mental Health in Europe', 2008, Copenhagen: WHO Regional Office for Europe.

60. World Health Organization, 'The European Mental Health Action Plan 2013-2020', 2015, [Online] available at http://www.euro.who.int/_data/assets/pdf_file/0020/280604/WHOEurope-Mental-Health-Acion-Plan-2013-2020.pdf?ua=1, accessed on December 20, 2019. 